ERNEST LAPOINTE AND QUEBEC'S INFLUENCE ON CANADIAN FOREIGN POLICY 
This page intentionally left blank 


\section{JOHN MACFARLANE}

\section{Ernest Lapointe and Quebec's Influence on Canadian Foreign Policy}

UNIVERSITY OF TORONTO PRESS

Toronto Buffalo London 
www.utppublishing.com

(C) University of Toronto Press Incorporated 1999

Toronto Buffalo London

Printed in Canada

ISBN $0-8020-44^{8} 7-5$ (cloth)

(क)

Printed on acid-free paper

\section{Canadian Cataloguing in Publication Data}

MacFarlane, John, 1963-

Ernest Lapointe and Quebec's influence on Canadian

foreign policy

Includes bibliographical references and index

ISBN $0-8020-4487-5$

1. Lapointe, Ernest, 1876-1941. 2. Canada - Foreign relations -

1918-1945.* 3. Canada - Politics and government - 1921-1930.*

4. Canada - Politics and government $-1930-1935 .^{*}$ 5. Canada -

Politics and government $-1935^{-1948}{ }^{*} \quad 6$. Cabinet ministers

- Canada - Bibliography. I. Title.

FC581.L36M33 1999 970 C99-930023-7

F1034.L34M33 1999

This book has been published with the help of a grant from the Humanities and Social Sciences Federation of Canada, using funds provided by the Social Sciences and Humanities Research Council of Canada.

University of Toronto Press acknowledges the financial assistance to its publishing program of the Canada Council for the Arts and the Ontario Arts Council. 
FOR DIANE 
This page intentionally left blank 